\title{
VOCÊ É O QUE VOCÊ VESTE? A ASSOCIAÇÃO DA AUTOIDENTIDADE DO GAY MASCỦLINO AO VESTUÁRIO DE LUXO
}

\author{
ARE YOU WHAT YOU DRESS? \\ THE ASSOCIATION OF THE MALE GAY SELF \\ IDENTITY TO LUXURY CLOTHES
}

Recebido $14 / 06 / 2012$ Aceito 01/06/2013

Joyce Gonçalves Altaf ${ }^{1}$ Irene Raguenet Troccoli²

Mara Bastos Moreira ${ }^{3}$

\section{RESUMO}

A emergência da identidade dos consumidores homossexuais modernos, favorecida pelas condições socioeconômicas e psicológicas proporcionadas pelo capitalismo, permitiu que estes se sentissem livres para expressar sua identidade, dentre outras formas, por meio da utilização de produtos e serviços. Assim, compreender o que leva este nicho de mercado a optar pelo consumo de determinada categoria de produto é, sem dúvida, de grande importância para as empresas que desejem trabalhar com público caracterizado por perfil atraente enquanto consumidor. Isso motivou o presente estudo qualitativo de caráter exploratório, que buscou identificar a relação que o consumo de vestuário de luxo por parte dos homossexuais masculinos pode ter com o desenvolvimento do seu eu estendido, assim como com a construção de sua autoimagem. A pesquisa foi realizada em quatro etapas, por meio de entrevistas com 12 homens, incluindo revisão bibliográfica, aplicação de formulário com escala de Likert e de formulário com escala semântica, e estudo dos resultados. Concluiu-se que o autoconceito influencia diretamente no comportamento de compra do homossexual masculino e que a maior parte dos entrevistados faz uso de vestuário de luxo para compor seu eu estendido.

Palavras-chave: Eu estendido; autoconceito; comportamento do consumidor homossexual; luxo.

${ }^{1}$ Possui graduação em Serviço Social pela Universidade Federal de Juiz de Fora - UFJF e em Administração pela Faculdade Metodista Granbery, pós-graduação em História Econômica pela Universidade Federal de Juiz de Fora - UFJF, curso de extensão em Marketing e Liderança pelo Marietta College e mestrado em Administração e Desenvolvimento Empresarial pela Universidade Estácio de Sá - UNESA. Atualmente é como professora das Faculdades Integradas do Instituto Vianna Júnior e da Fundação Educacional Machado Sobrinho. Juiz de Fora, Minas Gerais, Brasil. E-mail: jgaltaf@yahoo.com.br.

${ }^{2}$ Possui graduação em Ciências Econômicas pela Universidade Federal do Rio de Janeiro - UFRJ, mestrado e doutorado em Administração pela Pontifícia Universidade Católica do Rio de Janeiro - PUC/RJ. Atualmente é professora na Universidade Estácio de Sá UNESA. Rio de Janeiro, Rio de Janeiro, Brasil. E-mail: irene.troccoli@estacio.br.

${ }^{3}$ Possui graduação em Comunicação Social e especialização em Administração em Marketing pelo Centro universitário da Cidade - UniverCidade, especialização em Gestão de Projetos pela Fundação Getúlio Vargas - FGV e mestrado em Administração e Desenvolvimento Empresarial pela Universidade Estácio de Sá - UNESA. Rio de Janeiro, Rio de Janeiro, Brasil. E-mail: marabastos@globo. com. 


\begin{abstract}
The emergence of the identity of the homosexual modern consumer, favored by the social, economic and psychological conditions produced by capitalism, allowed homosexuals to feel free to express their identity, among other ways through the use of products and services. Thus, understanding what stimulates the consumption of a specific product category by this market niche is no doubt of great importance for the companies that intend to serve this public, considering their attractive consumption profile. This stimulated this exploratory qualitative study, that seeked to identify the relationship between luxury clothing consumption by homosexual men and the development of their extended self, and well as their self image construction. The four steps of the research, done with 12 men, were literature review, in-depth interviews, the filling of two forms (one with Likert scale and the other with a semantic scale), and the analysis of the results. The conclusion is that self concept directly influences the buying behavior of male homosexuals, and that most of the interviewees actually use luxury brands clothes to compose their extended selves.
\end{abstract}

Keywords: Extended self; self concept; male homossexual consumer behaviour; luxury.

\title{
1 INTRODUÇÃO
}

O consumo é um processo contínuo, que implica muito mais do que a troca de uma quantia financeira por uma mercadoria ou um serviço. O consumo envolve questões que influenciam o consumidor antes, durante e depois da compra bem como todo o processo de busca, de escolha e de tomada de decisão de compra de um produto, a experiência durante o consumo, o desempenho do produto após a compra e as consequências desta (HIRSCHMAN; HOLBROOK, 1982).

Quando se fala de consumo, fala-se não só de objetos tangíveis, mas de experiências, de ideias e de características intangíveis (SOLOMON, 2002). De acordo com Holbrook et al. (1996), muitas experiências de consumo - tais como fantasias, sentimentos e divertimento - estão por trás das decisões de compra e são importantes para o fenômeno do consumo. O consumo, antes um ato simbólico do que econômico (ROCHA, 1995), "[...] é a totalidade virtual de todos os objetos e mensagens constituídos em um discurso cada vez mais coerente. É uma atividade de manipulação sistemática de signo" (BAUDRILLARD, 1973, p. 66). Com o passar do tempo, os produtos deixaram de diferenciar-se por suas características intrínsecas para apresentarem uma diferenciação pelo valor simbólico atribuído a si e à sua marca (ROCHA, 1995).

No que se refere ao simbolismo e aos significados do consumo, os produtos são excelentes fontes de informação sobre as pessoas que os consomem (BELK, 1988). Paralelamente, as escolhas do consumidor são feitas por uma enorme variedade de razões não muito fáceis de prever e compreender (CAMPOS et al., 2005). Frequentemente, o consumidor vale-se do significado social dos produtos para moldar sua própria imagem (SOLOMON, 1983) e fala sobre si mesmo por meio dos bens personalizados que consome (MCCRACKEN, 1986).

É nesse contexto que se faz pertinente o estudo do comportamento do consumidor homossexual moderno, cuja emergência da identidade foi favorecida pelas condições socioeconômicas e psicológicas propiciadas pelo capitalismo (NUNAN, 2003), que permitiu que os homossexuais, entre outros indivíduos que fogem aos padrões tradicionalmente aceitos pela sociedade, sentissem-se livres para expressarem sua identidade, dentre outras formas, por meio da utilização de produtos e serviços. Além disso, fez com que o mercado voltado para o atendimento destas necessidades específicas se transformasse em um dos alicerces desta subcultura de consumo, definida por Hawkins, Mothersbaugh e Best (2007, p. 73) como "[...] um subgrupo distinto da sociedade cujos membros selecionam a si mesmos com base no compromisso compartilhado em relação a uma classe de consumo, marca ou atividade de consumo específica". 
Nesta linha de raciocínio, este artigo objetivou identificar a relação que o consumo de vestuário de luxo por parte dos homossexuais masculinos pode ter com o desenvolvimento do seu eu estendido, assim como com a construção de sua autoimagem. Neste esforço, ele buscou: 1) entender os valores fundamentais que orientam o consumo dos produtos de luxo para o público em geral, 2) compreender o conceito do eu estendido e sua aplicabilidade ao consumo de vestuário de luxo, identificando de que forma este pode contribuir para a construção da autoimagem do consumidor e do seu eu estendido e 3 ) entender a visão dos homossexuais masculinos sobre a contribuição do vestuário de luxo à construção de sua autoimagem e de seu eu estendido.

O artigo está dividido em cinco partes: 1) esta introdução; 2) a revisão bibliográfica; 3) a metodologia utilizada; 4) os resultados de pesquisa e 5) a conclusão e as limitações do estudo, assim como as recomendações para futuros trabalhos.

\section{REVISÃO BIBLIOGRÁFICA}

\subsection{Mercado consumidor homossexual masculino}

O estudo do mercado consumidor homossexual - não só o masculino - mostra-se relevante ao levar-se em conta o tamanho deste nicho em termos econômicos. A partir do censo de 2007, o Instituto Brasileiro de Geografia e Estatística (IBGE) incluiu uma pergunta sobre a orientação sexual dos respondentes. Como resultado, foi estimado que $10 \%$ da população brasileira é formada por homossexuais, o que representaria algo em torno de 18 milhões de pessoas. Trata-se de um número expressivo. Mesmo assim, percebe-se um descaso por parte dos órgãos públicos e de entidades comerciais no que se refere ao conhecimento mais aprofundado sobre $o$ homossexual brasileiro (CONSTÂNCIO, 2007).

Isto é, apesar do tamanho do Brasil em termos populacionais, poucas pesquisas têm sido realizadas no país a fim de traçar o perfil do público homossexual nacional tanto pelo ângulo de sua composição quanto pelo de suas preferências. Ademais, a maioria dessas pesquisas não são desenvolvidas por órgãos "oficiais", além de serem restritas quanto ao universo e ao respectivo público pesquisado: cada uma é realizada em ambientes e em situações diferentes, tais como em sites destinados aos gays ${ }^{4}$, lésbicas e simpatizantes (GLS), ou durante manifestações populares, como paradas organizadas pelos grupos de gays, lésbicas, bissexuais e transexuais (GLBT) realizadas em todo o país. Isso as torna pouco confiáveis, por três motivos (ALTAF, 2009). Em primeiro lugar, possivelmente por temerem o preconceito e a estigmatização, muitos sujeitos não revelam a sua verdadeira orientação sexual ou mentem sobre aspectos relacionados a ela, mesmo quando respondendo anonimamente, o que permite inferir que o número de homossexuais pode ser maior do que aquele evidenciado em pesquisas. Em segundo lugar, pode-se supor que a assunção da homossexualidade seja mais elevada junto aos estratos da sociedade caracterizados por maior escolaridade, dada a capacidade desses de, mais facilmente, aceitarem a diferenciação em relação à heterossexualidade, o que implicaria que censos e pesquisas que tragam resultados referentes a esta subcultura seriam naturalmente viesados. Em terceiro lugar, os critérios para se definir o que é ser homossexual variam conforme as características de cada estudo.

Considerando-se estas restrições, de acordo com Constâncio (2007), por semelhança

${ }^{4}$ No Brasil, o termo gay é usualmente adotado como sinônimo de homossexual masculino. Nos EUA e no Canadá, o termo homossexual está fora de uso, e é considerado relativamente pejorativo. Pesquisas recentes canadenses têm indicado que há diferença entre ambos os termos, com o homossexualismo sendo considerado um comportamento, e gay uma identidade; assim, homens que mantêm relações sexuais com outros homens podem não se identificar como gays (ver B. D. Adam, "Love and sex in constructing identity among men who have sex with men," International J. of Sexuality and Gender Studies, vol 5, no. 4, 2000). 
dos dados coletados em cada uma destas pesquisas isoladas é possível obter um perfil aproximado da composição do público homossexual no Brasil. Uma delas é a que foi encomendada ao Instituto Brasileiro de Opinião Pública e Estatística (Ibope), pelo Ministério da Saúde em 2003 (MINISTÉRIO DA SAÚDE/IBOPE, 2002), e que traçou o perfil do segmento homossexual, com base na tabulação de 1.200 entrevistas feitas durante as três maiores paradas gay do país, a de São Paulo, a do Rio de Janeiro e a de Salvador. Com base nas entrevistas, constatou-se que: $57 \%$ eram brancos, $11 \%$ negros e $32 \%$ mulatos, pardos e morenos; $48 \%$ situavam-se nas classes A/B, $35 \%$ na classe $\mathrm{C}$ e $18 \%$ nas classes $\mathrm{D} / \mathrm{E} ; 47 \%$ tinham até 24 anos de idade e $53 \%$ mais do que 24 anos de idade; $16 \%$ cursaram até 8 a série do ensino fundamental, $48 \%$ o ensino médio e $35 \%$ o ensino superior; $15 \%$ possuíam renda até dois salários mínimos, $27 \%$ entre mais de dois e cinco salários mínimos, 23\% entre mais de cinco até 10 salários mínimos, e 20\% entre mais de 10 e 20 salários mínimos; $60 \%$ trabalhavam em período integral, $20 \%$ em meio período e $19 \%$ não trabalhavam.

Apesar das limitações intrínsecas deste levantamento do governo (por exemplo, o fato de ser tão somente uma pesquisa de opinião, sem maiores rigores científicos na sua aplicação), ele deu indícios de que os homossexuais que assumem sua identidade sexual representariam não só boa parcela da população brasileira, como também seriam contingente relevante com alto poder de consumo e com escolaridade relativamente elevada, o que sugere que são um importante nicho consumidor. A esse respeito, Azevedo et al. (2012) ressaltam que o segmento GLBT, que têm buscado constantemente o reconhecimento e o respeito aos direitos civis, é composto por profissionais que atuam em diversas áreas da sociedade.

Ademais, de acordo com o estudo realizado por Mariano e Lima (1999), o consumidor homossexual possui perfil específico: é exigente e, muitas vezes, só estabelece relação com marcas ou com produtos quando há valor social acrescido. Além disso, apesar dos recentes avanços na iniciativa de adoção de crianças por parte de casais homossexuais brasileiros, muitos não possuem filhos, o que lhes permite destinar mais renda para consumo imediato. Assim, embora esta conclusão deve ser considerada de forma cautelosa devido aos motivos apresentados, o homossexual com maior poder de compra teria, como aspecto diferencial, ser um consumidor requintado que deseja produtos ou serviços de qualidade - teoricamente de valor elevado - e duradouros.

Todavia, compreender o que leva este nicho de mercado a optar pelo consumo de determinada categoria de produto é, sem dúvida, de grande importância para as empresas que desejam trabalhar com público caracterizado por perfil atraente enquanto consumidor. Afinal, conforme Granato e Pereira (2011, p. 16), "na era contemporânea os hábitos dos consumidores tornaram-se índices estratégicos na tomada de decisão das organizações".

Uma das primeiras informações a respeito do perfil do consumo homossexual pode ser obtida em Soares (2000): indiferentemente da classe social, os homossexuais dariam muito mais valor à imagem, à aparência e à moda do que os heterossexuais, independentemente do estilo de roupa adotado - alguns homossexuais iriam se vestir de maneira "clássica", ao passo que outros adotariam um visual "extravagante".

Nunan (2003), quando se refere a padrões de consumo, destaca que gays e lésbicas gastariam maiores quantias do que heterossexuais em itens como viagens, carros, cartões de crédito, restaurantes, roupas, perfumes, produtos eletrônicos, dentre outros. Além disso, a autora enfatiza que, se comparados com a população heterossexual, esses consumidores também seriam mais jovens, mais bem informados social e politicamente, mais preocupados com moda e mais fiéis a determinadas marcas. Concluindo, ela acrescenta que os homossexuais concederiam muita importância às amizades, gostando de presentear entes queridos - o que potencializa seu potencial de consumo e os torna um público ainda mais interessante para o marketing. 
Outros autores (BOWES, 1996; DELOZIER; RODRIGUES, 1996) acrescentaram que muitos homossexuais são trabalhadores autônomos preocupados com o seu bem-estar físico e psicológico, características que sugeririam uma população aberta a novas tecnologias. Reforçando as referidas especificidades comportamentais dessa subcultura, Lukenbill (1999) distinguiu quatro áreas nas quais consumidores que se autoidentificam como gays diferem de consumidores heterossexuais: são mais individualistas, possuem necessidade elevada de associarem-se com outras pessoas (devido ao isolamento social de que são constantemente objeto), procuram distanciar-se da rotina do dia a dia buscando novas experiências de vida e precisam aliviar altos níveis de estresse.

\subsection{0 mercado do luxo}

Definir produto de luxo não é tarefa das mais simples. Afinal, esse é um conceito relativo - o que é luxo para uns pode ser absolutamente comum para outros. Assim, tanto a definição do termo quanto a escolha dos produtos que serão considerados de luxo são variáveis, de acordo com a classe socioeconômica de cada indivíduo, associada a aspectos psicológicos, tais como motivações e estilo de vida. Em estudos de Administração de Empresas e de Marketing, convenciona-se chamar de luxo aquele produto ou serviço dotado de qualidade, de estética, de preço e de imagem de marca superior aos convencionais, podendo pertencer a várias categorias de bens - embora algumas delas, naturalmente, estejam mais associadas ao conceito (D’ANGELO, 2004), como, por exemplo, as joias, as roupas, os acessórios e os carros de luxo. A partir da contribuição de autores como Castarède (2005), Allérès (2000), Haie (2002), Lipovetsky e Roux (2005) e Baudrillard (1981), considera-se neste artigo o conceito de luxo de forma não restrita apenas à classe social, mas também considerando outras características.

Para muitos, luxo significa algo caro e não democrático, de acesso restrito. Entretanto, não se limita a isto. Afinal, de acordo com Castarède (2005, p. 24), "luxo é o que não é corriqueiro e está relacionado ao talento, ao garbo, à magnificência e à celebração. É tudo que não é necessário". Além disso, o autor acrescenta que "os produtos de luxo não são banalizados e carregam consigo uma aura de sonho, uma conotação imaterial. Seu preço é característico dos critérios de escassez que eles representam". Já para Allérès (2000), o luxo é o que melhor corresponde à expressão dos desejos e das emoções humanas, de forma que, através dele, pode-se conhecer um pouco do universo das pessoas que o consomem.

Duas visões a respeito do luxo são definidas por Castarède (2005). A primeira pertence aos puristas, que tratam o luxo como consumo de alto investimento, classificando os produtos como patrimônio. Na segunda, o luxo é o supérfluo, sinônimo de futilidade e totalmente desnecessário. D'Angelo (2004, p. 40) ressalta as características destes produtos, que são caros (preço mais elevado em relação a produtos que oferecem a mesma funcionalidade), dotados de qualidade superior (tecnologia empregada, matéria-prima excepcional e fabricação muitas vezes artesanal), raros (produzidos com exclusividade e distribuídos de maneira seletiva e exclusiva), esteticamente bem elaborados (possuidores de uma aparência particular, o que induz ao consumo emocional e hedônico), dotados de uma marca famosa (de imagem reconhecida em diversos lugares do mundo), adquiridos por uma clientela especial (devido à capacidade de apreciação do produto ou apenas ao elevado poder aquisitivo do consumidor), e "esnobes" (por valerem-se da atratividade de pequenos grupos "formadores de opinião" para a difusão do produto). A combinação desses elementos é que confere a imagem de luxo a um produto, criando o imaginário e o glamour que circulam o objeto, algo fundamental para a perpetuação de sua imagem.

Lipovetsky e Roux (2005) concordam que, hoje, o luxo não se limita mais apenas à peque- 
na parcela da população com alto poder aquisitivo, mas sim a outros indivíduos que dele pretendem desfrutar e que possuem a renda mínima necessária para isso. A partir disso, pode-se depreender que há uma ligação entre as categorias de produtos de luxo e sua utilização pelos diferentes estratos sociais. Não surpreende, portanto, que, segundo Allérès (2000), as classes sociais ditas intermediária e média tenham aliado-se à classe dita abastada no consumo de produtos de luxo, embora cada uma delas siga modelos de consumo específicos e se localize em categorias de luxo diferentes entre si - respectivamente, luxo intermediário, luxo acessível e luxo inacessível.

\subsection{Marca}

Nesta pesquisa, adota-se a definição de marca apresentada por Aaker (1998): uma marca é um nome diferenciado e/ou um símbolo (tal como logotipo, marca registrada, ou desenho de embalagem) destinado a identificar os bens ou serviços de um vendedor ou de um grupo de vendedores e a diferenciar esses bens e serviços daqueles dos concorrentes.

Para Churchill Junior. e Peter (2000), as marcas são um dos elementos fundamentais de informação de que os clientes dispõem para ajuda-los no processo de escolha e para reduzir os riscos da aquisição. Os nomes de marca asseguram ao cliente que, em uma próxima compra, ele pagará pela mesma qualidade que recebeu na última vez. Por meio de um nome forte, socialmente reconhecido, os consumidores conhecem as características fundamentais de um bem ou de um serviço, assim como suas qualidades, estabelecendo maior ou menor vínculo com a marca o que influenciará sua escolha na hora da compra.

Entretanto, existe um ponto que deve ser bem definido para o melhor entendimento do que é a marca: ela é diferente de produto. 0 principal propósito da marca é o de distinguir o produto, de maneira com que ele possa ser facilmente identificado e preferido. Além disso, as marcas são os principais recursos que podem ser utilizados para combater a tendência natural à "comoditização", como ressalta Tavares (1998). Assim sendo, a marca não se baseia só em aspectos externos do produto, mas também nos internos. O resultado são os diversos níveis de produtos e de serviços; o público decodifica todos os sinais emitidos por uma marca por meio de seus produtos, de seus serviços, de seus programas de comunicação, de seus empregados e de seu trato com as questões sociais e ambientais - fazendo surgir a imagem da marca.

De acordo com Gardner e Levy (1995), o conceito de imagem na literatura mercadológica surgiu em 1955, estando vinculado à constatação de que os consumidores compram produtos não somente por seus atributos e funções físicas. Desse modo, os significados que são conferidos pela marca aos produtos são extremamente importantes. Tavares (1998, p. 64) argumenta que "[...] a imagem, nessa perspectiva, significava personalidade, e os produtos, como as pessoas, têm personalidade". Segundo o autor, a imagem que se constrói de uma marca decorre das impressões positivas, neutras ou negativas que cada consumidor desenvolve a partir do contato com ela e de seu contexto de atuação. A partir dessa perspectiva, pode-se estabelecer o que se entende por imagem.

De acordo com o modelo de Keller (1993), a construção da imagem da marca está alicerçada em quatro fatores determinantes: os tipos de associações de marca, a favorabilidade das associações, a força das associações e a exclusividade das associações. Quando o autor aborda os tipos de associações de marca, refere-se à análise de atributos, de benefícios e das atitudes que o sujeito constrói e passa a ter em relação a elas.

As associações referentes aos benefícios e às atitudes construídas pelo sujeito dizem respeito às percepções que estes constroem ao longo das suas experiências, as quais, conforme Baldissera (2000), são compreendidas como a imagem-conceito e a construção dos processos 
de significação. A partir dessa construção tem-se, então, que o conceito de imagem de marca são percepções sobre esta última, refletidas por associações que surgem na mente do indivíduo (KELLER, 1993). Esse princípio de associações também é corroborado por Biel (1992) e por Aaker (1998). Esse último ressalta que uma associação é algo ligado a uma imagem na memória, que varia conforme um grau de força.

Desta forma, as associações são elos de informações ligados ao elo da marca na memória do sujeito, contendo o significado da marca (KELLER, 1993). Quanto mais favoráveis, fortes e exclusivas forem as associações, maior será a percepção de valor de marca construída pelo indivíduo, principalmente se a ligação deste com a marca for baseada em muitas experiências ou em exposições à comunicação (AAKER, 1998). Sendo assim, o conceito de imagem da marca é definido como "[...] um conjunto de associações usualmente organizadas de alguma forma significativa" (AAKER, 1998, p. 115), que, conforme Aaker (1998), poderá estar ou não refletindo a realidade objetiva, pois trata-se de percepções do sujeito.

No caso do presente trabalho, que busca compreender marcas de vestuário na formação do eu estendido do consumidor homossexual masculino, pressupõe-se que a marca, para ser adotada por este público, precisa passar uma imagem que vá ao encontro das necessidades culturais e dos desejos destes.

\subsection{Eu estendido e o autoconceito}

Belk (1988), com o objetivo de explicar o porquê de alguns produtos adquirirem significado substancial para um indivíduo ou de serem utilizados para demonstrar aspectos particulares importantes da personalidade daquela pessoa para os outros, desenvolveu a Teoria do Eu Estendido. Para o autor, os indivíduos podem ser compreendidos a partir do exame das suas posses, com o termo eu estendido relacionando-se a tudo o que um indivíduo considera como seu. Ampliando seu raciocínio, Belk faz a distinção entre self (eu) e self estendido (meu). Segundo ele, diversos objetos podem ser apropriados ao self, tais como posses pessoais, pessoas, lugares e posses de grupos. Ademais, à medida que essas posses representam a formação ou expressão de parte do self do consumidor ou auxiliam-na; elas fazem parte do seu self estendido (BELK, 1988; TIAN; BELK, 2005), o que instaura uma íntima relação entre consumo e identidade.

Hawkins, Mothersbaugh e Best (2007) colaboram com a definição de eu estendido. Para os autores ele consiste no eu somado às posses - isto é, as pessoas tendem a definir a si mesmas, em parte, por meio das posses. Assim, algumas posses não são apenas manifestações da autoimagem de uma pessoa; são parte integral de sua autoidentidade. Partindo da afirmação desses autores de que as posses são parte integral da autoimagem do indivíduo, pode-se concluir que as pessoas são, até certo limite, o que elas possuem. Desse modo, se alguém perde suas principais posses, torna-se uma pessoa um pouco diferente. Para Solomon (2002), o uso das atividades de consumo como forma de expressão da identidade ou de definição do eu é frequentemente relacionado a fortes associações entre produtos e papéis sociais. O consumidor aprendeu que diferentes papéis são acompanhados de atividades e de produtos que reforçam ou que ajudam a os definir.

Pode-se considerar, portanto, que o conceito de eu estendido vai ao encontro do comportamento do consumidor homossexual que, de acordo com Nunan (2003), é mais preocupado com moda, com objetos de luxo e com marcas - itens que fazem parte da gama de produtos dotados de valores hedônicos e que se relacionam diretamente com a extensão do eu.

No que diz respeito à associação entre o eu estendido e o consumo de produtos de marcas de luxo, deve-se inicialmente ressaltar que, no universo do luxo, é muito importante o con- 
sumo como construção da identidade do indivíduo. Comumente, este último assume um comportamento de compra que está de acordo com o estilo de vida das classes mais altas e rejeita o que se assemelha ao das classes mais baixas (VIGNERON; JOHNSON, 2004). De acordo com Belk (1988), o conceito de materialismo torna-se muito importante na medida em que, sendo abstrata, a identidade precisa evidenciar-se mediante aspectos concretos que são, prioritariamente, aquilo que se faz e aquilo que se tem. Para Richins (1991, p. 28), "consumidores materialistas podem enxergar o consumo de luxo como uma forma de alcançar a felicidade e podem usar esse mesmo critério para avaliar o seu sucesso e o dos outros".

Já no que se refere ao construto do autoconceito, tanto ele como o self (o "eu") têm sido amplamente estudados pela psicologia e pelo marketing - neste último, mais especificamente na área de comportamento do consumidor - devido à eficácia de ambos os construtos para o aprofundamento do estudo das motivações ao consumo de bens e de serviços. Muito embora Cavallet-Mengarelli $(2008$, p. 32) afirme que autoconceito e self "[...] se confundem em alguns estudos e abordagens", eles podem ser entendidos de formas diferentes. Assim, para Doron e Parot $(1998$, p. 12) autoconceito seria "[...] uma representação de si mesmo no sistema de conhecimento do indivíduo", ao passo que self remeteria a uma percepção mais ampla, à "[...] aquilo que define a pessoa em sua totalidade" (p. 34). Corroborando essa visão, Cavallet-Mengarelli (2008, p. 22) ressalta que "o self é a pessoa enquanto lugar da atividade psíquica em sua totalidade".

O que se pode perceber é que o autoconceito, que pode ser representado como a forma pela qual um indivíduo vê a si mesmo, o "quem sou eu", tem sido trabalhado por diversas disciplinas e a partir de múltiplas interpretações. A percepção de que o consumidor, além de orientado por aspectos funcionais, é significativamente afetado por aspectos simbólicos, impulsionou o estudo deste construto no que se refere ao comportamento do consumidor (SIRGY, 1982), muito embora a pesquisa do autoconceito no estudo do comportamento do consumidor se apresente de maneira fragmentada e difusa (SIRGY, 1982; REED II, 2002). Sirgy (1982), em sua ampla revisão teórica crítica de pesquisas relacionadas ao autoconceito, afirmou que, de forma geral, o autoconceito tem sido determinado nas pesquisas de marketing como "[...] a totalidade dos pensamentos e sentimentos do indivíduo a respeito de si mesmo como um objeto" (ROSEMBERG, 1979, p.1).

$O$ estudo do autoconceito nas áreas de marketing e de comportamento do consumidor buscou, em muitos casos, traçar paralelos entre o autoconceito do indivíduo e a imagem do produto consumido. Quanto maiores a visibilidade, a personalidade e a variabilidade do produto, maior a possibilidade de comunicação do autoconceito por meio dele, e, dessa forma, mais simbólico é o consumo. Sirgy (1982) resgatou algumas contribuições importantes para a teoria do autoconceito, dentre elas a afirmação de Grubb e Grathwohl (1967) de que os bens comunicam significados simbólicos e de que o comportamento do indivíduo visa realçar e proteger o autoconceito. Schenk e Holman (1980) introduziram uma importante visão, que substituiu a proliferação de conceitos e incluiu um componente comportamental: a abordagem do autoconceito de uma situação específica, na qual o indivíduo escolhe qual eu vai expressar, de acordo com as características do momento ou do grupo em que está inserido. Quando relacionado a imagens de produtos, o autoconceito vem sendo tratado por diferentes abordagens: pelo relacionamento da imagem do produto com uma imagem estereotipada do usuário ou com o autoconceito.

Nesse sentido, destaca-se a teoria da congruência entre a imagem do produto e a autoimagem (SIRGY, 1982): os consumidores, em geral, buscam produtos e marcas que sejam compatíveis com a sua identidade, portanto, produtos que transmitem certa imagem - por exemplo, status social - podem ativar benefícios similares na pessoa. O mesmo autor afirma que é essa visão, de que os consumidores são motivados a se aproximar de produtos que se encaixem em 
suas autopercepções, que a maioria dos estudos da área tem tomado por base. Na teoria da congruência de Sirgy (1982), uma percepção de valor de autoimagem (positivo ou negativo) interage com uma percepção de valor da imagem do produto (positivo ou negativo). A autoestima procura por produtos que elevem o valor de autoimagem, ao passo que a autoconsistência procura por produtos que não contrariem sua autoimagem, atuando como fatores mediadores. Sirgy (1982) expõe, ainda, o conceito de atitude global da pessoa, que engloba a autoestima e a autossatisfação, e trata-a como um julgamento consciente da relação entre o eu real de um indivíduo e seu eu ideal ou social. Essa definição deixa explícita a situação de comparação que o indivíduo faz entre seu autoconceito real e aquilo que ele gostaria de ser e entre seu autoconceito e sua percepção de outros indivíduos de seu grupo social.

A aplicação do construto do autoconceito ao mercado do luxo deve ser realizada tendo em vista que, apesar da importância dos elementos "construtores" deste, sua sustentação encontra-se em elementos muito mais abstratos do que a idealização e a concretização de um produto diferenciado dos demais de sua categoria. Em outras palavras, os produtos diferenciados, além das qualidades objetiva e subjetiva, representadas, respectivamente, pela funcionalidade e pela estética, possuem uma dimensão simbólica que necessita ser considerada (ALLÉRÈS, 2000). Mais do que qualquer outro produto, os itens de luxo são comprados não por aquilo que são, mas pelo que significam (AMUI, 2006).

Não é por outro motivo que Vigneron e Johnson (2004) reúnem os significados presentes no consumo de luxo em cinco dimensões empregadas para explicar o conceito, incluindo a extensão do eu. São elas:

1. a conspicuidade: Reflete uma busca por representações ou por posição social através da exposição e da ostentação no consumo;

2. a exclusividade: A produção limitada ou a escassez de um produto refletem a exclusividade procurada pelos consumidores de luxo e, por isso, interferem nas escolhas das marcas por parte destes;

3. a qualidade: Os produtos de luxo precisam ter qualidade superior aos demais ou pelo menos aparentar ter;

4. o hedonismo: O consumo de luxo transmite sua dimensão hedônica quando os consumidores estão em busca de prazer, de recompensa e de realização pessoal através da compra de determinado produto. Essa sensação é despertada mais pelos benefícios emocionais subjetivos do que pelos benefícios funcionais do objeto;

5. a extensão do eu: No universo do luxo, o consumo como construção da identidade do indivíduo também é muito importante. Comumente, este assume um comportamento de compra similar ao estilo de vida das classes mais altas, rejeitando aquele que se assemelha ao das classes mais baixas. $O$ conceito de materialismo torna-se muito importante uma vez que, por ser abstrata, a identidade precisa evidenciar-se mediante aspectos concretos que são, prioritariamente, aquilo que se faz e aquilo que se tem (BELK, 1998). Segundo Richins (1991), o consumo de luxo não só significaria o alcance da felicidade no caso dos consumidores materialistas como também seria um sinalizador de sucesso pessoal.

Dando seguimento a este assunto, Hawkins, Mothersbaugh e Best (2007) explicam que alguns produtos adquirem significado substancial para um indivíduo ou são utilizados para sinalizar aspectos particularmente importantes da personalidade de uma pessoa para as outras - colo- 
cação que remete à Teoria do Eu Estendido, de Belk (1988, p. 144): o eu estendido consiste no eu somado às posses; isto é, as pessoas tendem a definir a si mesmas em parte por meio das posses. Assim, algumas posses não são apenas manifestações da autoimagem de uma pessoa; são parte integral de sua autoidentidade".

\section{METODOLOGIA}

O universo desta pesquisa são os homens brasileiros que assumem identidade homossexual, dos quais foram selecionados 12 deles, indicados pelo Movimento Gay de Minas e pelo critério de bola de neve. A escolha obedeceu a critérios pré-determinados (GASKELL, 2004), visando a maior homogeneidade: posicionamento geográfico (restrição à região sudeste do Brasil) e renda (obtida de atividades não ligadas a posicionamento assumido como transexuais, travestis e drag queens, com o mínimo mensal definido em $\mathrm{R} \$ \mathbf{m i l}$ ). Quanto ao número de sujeitos, o relativo pequeno número encontra justificativa em Eisenhardt (1989), para quem o número ideal de entrevistados para estudos como o proposto é de quatro a 10, uma vez que menos de quatro pode implicar resultados distorcidos pelo pequeno tamanho do conjunto e mais de 10 também pode implicar vieses, tendo em vista a elevada complexidade trazida pela análise de entrevistas em profundidade. Neste estudo, a adição de dois elementos ao grupo sugerido, com base no máximo de 10, foi entendida como não capaz de implicar vieses, dada a relativa pequenez do acréscimo, além de ter sido compreendida como forte enriquecedora dos resultados qualitativos à medida que as entrevistas eram realizadas.

Os sujeitos foram objeto de três experimentos. O primeiro foram entrevistas em profundidade, cujo conteúdo foi posteriormente objeto de análise de discurso - no caso, seguiu-se a tendência apontada por Pinto e Lara (2008), cujo levantamento indicou que, juntamente com a análise de conteúdo, essa técnica de análise das evidências foi utilizada em quase $85 \%$ dos artigos sobre comportamento do consumidor veiculados ao longo de um decêndio nos veículos brasileiros mais representativos da produção acadêmica da área de marketing. Por meio dessa técnica foi possível realizar uma leitura atenta das descrições de cada um dos entrevistados, com foco na busca de unidades de significados e em transcrições dos principais trechos das entrevistas que relacionam a proposição do autoconceito como um construto influenciador do comportamento do consumidor de produtos de luxo.

O segundo e o terceiro experimentos realizados encontram justificação acadêmica para complementar o entendimento trazido pelos discursos, muito embora sua aplicação tenha se dado sobre pequeno número de indivíduos:

1) Aplicação de escala de diferencial semântico composta por pares de adjetivos bipolares, para a medição do seu autoconceito (ou seja, da sua autoimagem) e de seu conceito quanto ao vestuário de luxo. Este experimento apoia-se em Hawkins, Mothersbaugh e Best (2007), os quais indicam que a utilização da autoimagem no marketing requer que ela seja mensurável, sendo a abordagem de medida mais comum o diferencial semântico. No caso, foram utilizados 16 pares, inspirados nas propostas originais de Ross (1971) e de Malhotra (1981), que foram fundidas e ajustadas a partir das contribuições advindas da aplicação de um pré-teste: 1 ) bruto/ delicado, 2) agitado/calmo, 3) informado/desinformado, 4) dominante/submisso, 5) econômico/ perdulário, 6) agradável/desagradável, 7) contemporâneo/antiquado, 8) organizado/desorganizado, 9) racional/emocional, 10) jovem/maduro, 11) formal/informal, 12) conservador/liberal, 13) complexo/simples, 14) sem cores/colorido, 15) fraco/forte e 16) modesto/orgulhoso. A partir dos resultados da aplicação da escala semântica, observaram-se os pares de adjetivos bipolares 
em que a pontuação para o autoconceito e para o conceito quanto ao vestuário de luxo situavamse mais ou menos próximas uma da outra. Com isto, visou-se enriquecer o entendimento das percepções dos entrevistados de duas formas: a) verificando quando havia ou não convergência entre ambas as percepções por parte dos entrevistados e b) confrontando posicionamentos obtidos via a aplicação desta escala que, eventualmente, para um mesmo entrevistado, fossem conflitantes com aqueles obtidos da análise do discurso livre apresentado na entrevista.

2) Colocação de seis afirmativas a serem avaliadas e respondidas por meio de escala de Likert de sete pontos, com os consumidores expressando seus níveis de concordância, desde "concordo plenamente" até "discordo plenamente". As afirmativas foram aquelas propostas por Sivadas e Machleit (1994) para medir até que ponto um item foi incorporado ao eu estendido. Portanto, serviram para avaliar a incorporação, ao eu estendido dos entrevistados, do item de vestuário por eles apontado como destacado em seu consumo de marcas consideradas de luxo. Os resultados das marcações tiveram em seguida suas médias calculadas para cada um dos entrevistados e foram apresentados em gráficos, o que possibilitou uma visualização rápida do nível de concordância ou de discordância do grupo como um todo a cada afirmativa. As seis questões colocadas foram as seguintes: a) meu (minha)____ me ajuda a alcançar a identidade que desejo ter; b) meu (minha) ___ _ me ajuda a diminuir a lacuna entre o que sou e o que tento ser; c) meu (minha) ____é fundamental para a minha identidade; d) meu (minha) ___é parte de quem eu sou; e) se meu (minha)____ for roubado(a), me sentirei como se tivesse perdido minha identidade e f) eu obtenho parte da minha identidade com meu (minha)___. No caso, cada lacuna das frases foi preenchida com "marca preferida de vestuário", para se alcançar o objetivo final da pesquisa.

Tendo-se definido a metodologia para o levantamento dos dados, inicialmente realizouse um pré-teste do instrumento junto a três respondentes, exercício que serviu para o aperfeiçoamento do instrumento de pesquisa e do próprio roteiro.

\section{RESULTADOS}

\subsection{Quanto ao eu estendido}

A representação das respostas quanto à avaliação da incorporação do consumo de marcas de luxo ao eu estendido, encontra-se nas figuras de 1 a 6 e é acompanhada de trechos selecionados das entrevistas que foram considerados ilustrativos.

Vale relembrar que a proposição metodológica de Sivadas e Machleit (1994) implica que quanto mais perto o resultado estiver da unidade, maior será a concordância quanto à esta incorporação e vice-versa: quanto mais perto de sete, maior será a discordância. Já o ponto quatro, por ser ponto central da escala, pode ser considerado como o ponto da indiferença do entrevistado quanto à afirmação proposta. 


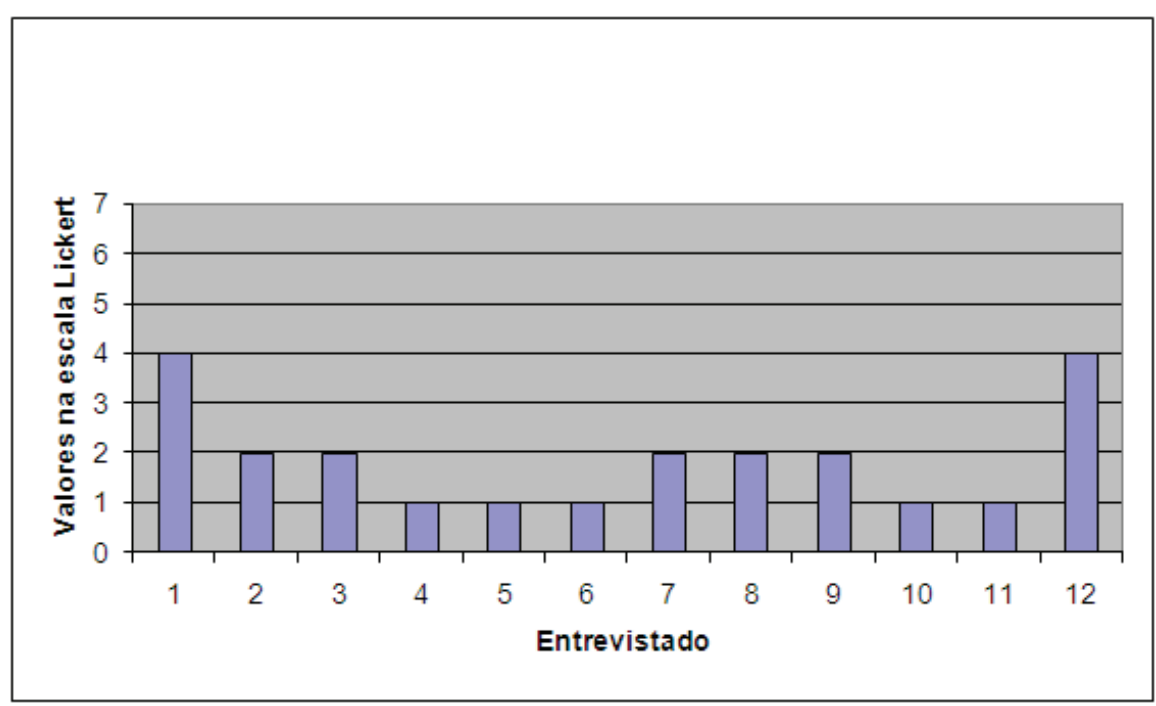

Figura 1 - Respostas à afirmativa "a"

Fonte: Elaboração própria

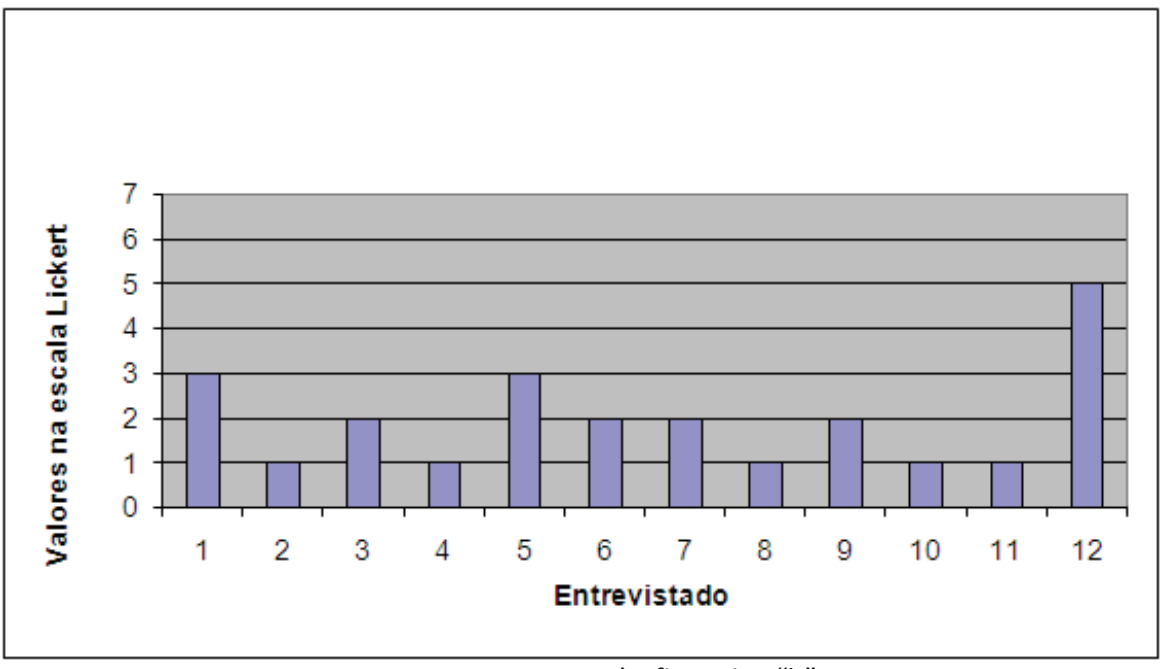

Figura 2 - Respostas à afirmativa "b"

Fonte: Elaboração própria

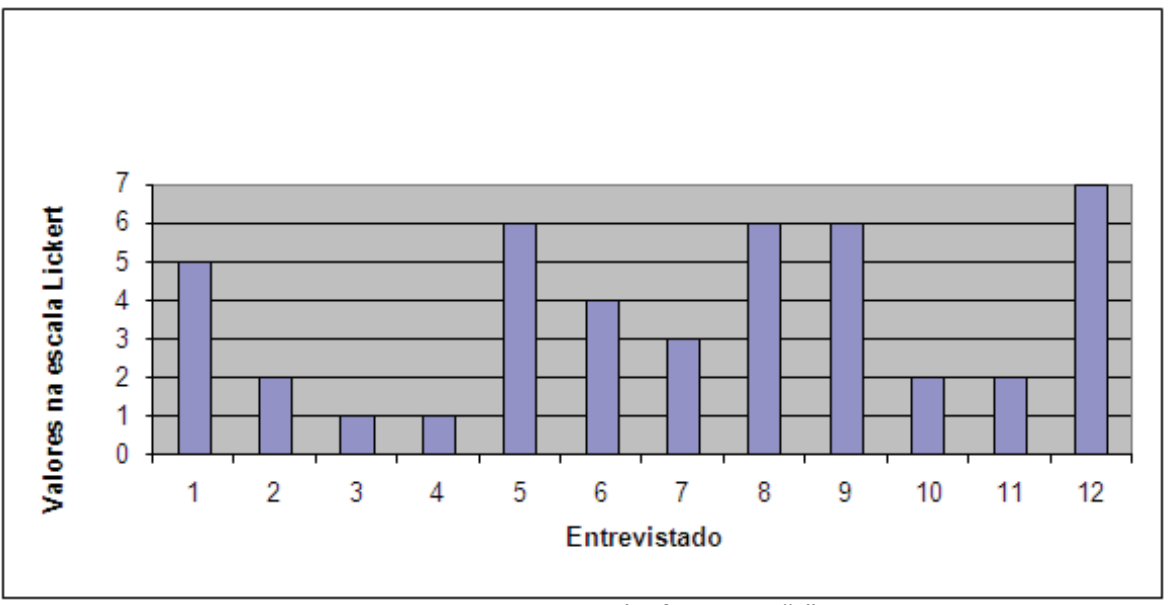

Figura 3 - Respostas à afirmativa "c" 


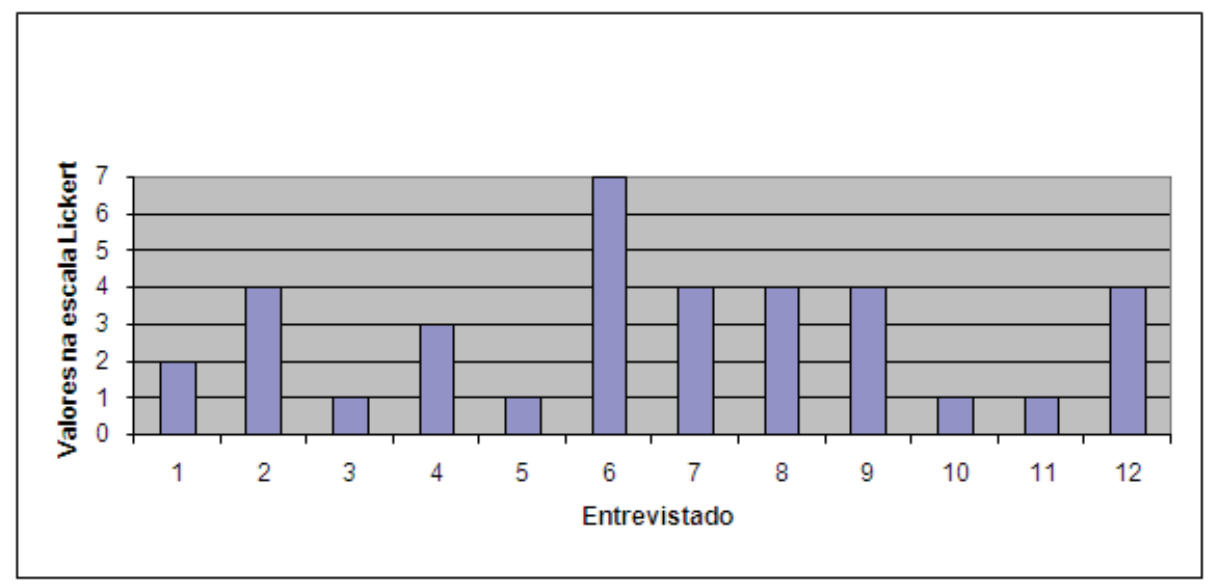

Figura 4- Respostas à afirmativa "c"

Fonte: Elaboração própria

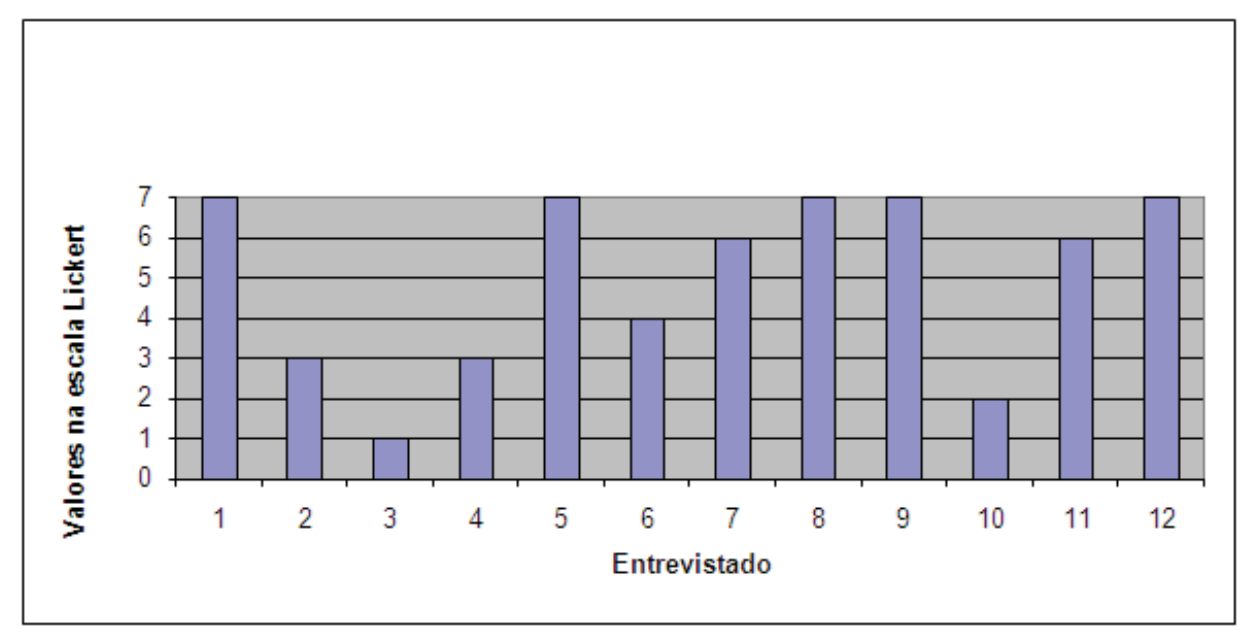

Figura 5 - Respostas à afirmativa "e"

Fonte: Elaboração própria

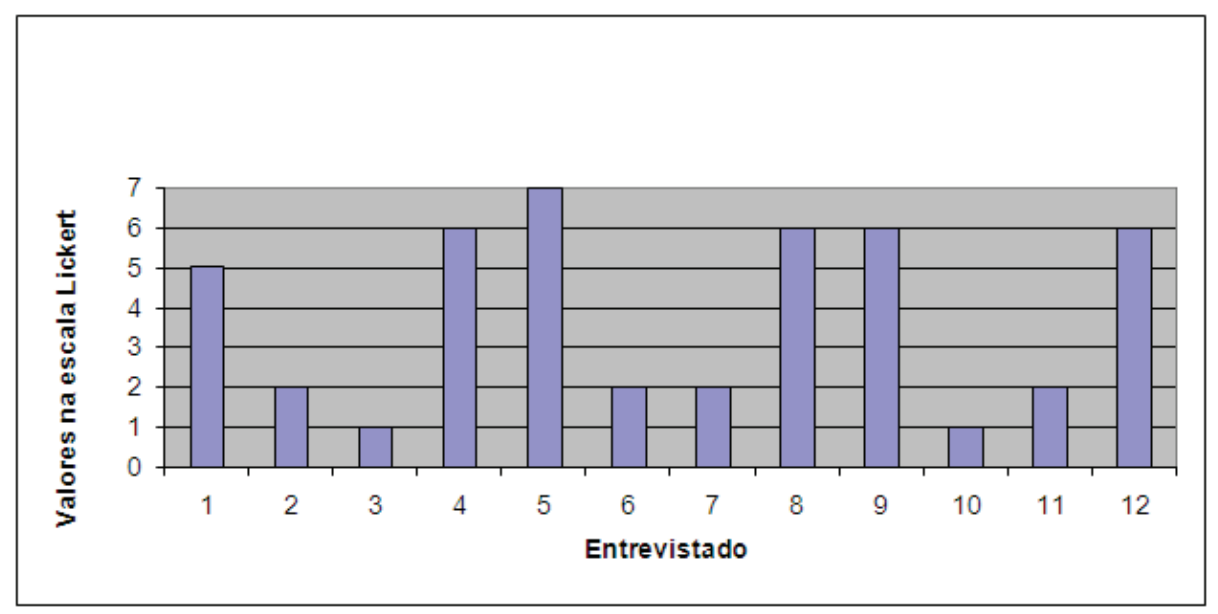

Figura 6 - Respostas à afirmativa " $\mathrm{f}$ "

Fonte: Elaboração própria 


\section{Pode-se observar que:}

1) A afirmação "a" (minha(s) marca(s) preferida(s) de vestuário me ajuda(m) a alcançar a identidade que desejo ter) teve a grande maioria dos respondentes tendendo à concordância, com cinco deles manifestando-se em concordância plena já que marcaram a unidade. Alguns discursos respaldaram esse posicionamento:

Você é o que você veste (Entrevistado n. 2)

Quando estou trabalhando procuro usar roupas que passam a ideia de uma pessoa bem sucedida. Por exemplo, adoro os ternos da (marca) Hugo Boss. Penso que quem usa essa marca é bem sucedido, e, como esse é meu maior desejo profissional, procuro sempre usar essa marca. Acho que, na minha profissão (advogado), a imagem é bem importante (Entrevistado n.11).

2) A afirmação "b" (minha(s) marca(s) preferida(s) de vestuário me ajuda(m) a diminuir a distância entre o que eu sou e o que eu tento ser) também apresentou grande concordância, com apenas três entrevistados afastando-se do ponto de número dois. Isto mostra que o vestuário é considerado importante para a redução da dicotomia entre o que o entrevistado é e o que ele deseja ser:

Quando era mais jovem eu era completamente dependente de marca. Morava em São Paulo e detestava falar que sou do interior de Minas. Acho que usava marcas bem paulistas para fazer com que me encontrasse dentro de um grupo. Lembro que gostava de usar a marca Lacoste. Hoje detesto porque acho que quem usa essa marca parece que não tem personalidade. Fica todo mundo meio igual (Entrevistado n. 5).

Estou iniciando a minha carreira e sei que hoje em dia imagem é fundamental. Se não estou bem vestido eu me sinto frágil. Acho que, quando uso um terno bacana, a postura do cliente mediante a mim é diferente. Eles me respeitam mais. Afinal, "novinho", gay e mal vestido ninguém merece, né? (Entrevistado n. 11).

Uso a marca de acordo com a ocasião. Quando vou a uma balada ou saio com amigos homossexuais eu me visto de uma forma. Quando saio com amigos héteros ou com alguém da minha família (disse que os pais possuem consciência da sua orientação sexual, mas nunca falou abertamente porque não considera necessário) me visto de outra. Pensa: se eu chego para trabalhar com uma das minhas camisas de balada, meu chefe não me aceita nunca mais (risos). Imagina se eu chego com uma camisa cheia de brilhos em pleno Fórum (Entrevistado n. 11).

3) A afirmação "c" (minha(s) marca(s) preferida(s) de vestuário é (são) fundamental(is) para minha identidade) registrou opiniões muito variadas: quatro respondentes tenderam claramente a discordar, e cinco preferiram posicionar-se próximos à concordância. De fato, esta falta de consenso ficou evidente em alguns discursos, tais como aqueles que evidenciaram claramente que, por mais que a marca não seja fundamental, ela favorece a identidade:

Eu uso o que gosto. Tenho minha própria identidade. Não acredito que uma marca possa ser a principal responsável pela minha forma de ser, ver e pensar o mundo. Acredito sim é que, quando quero passar alguma mensagem, uma determinada marca me ajuda a fazer isso. Por exemplo: se estou com meus amigos, adoro as roupas da (marca) Aramis porque elas reforçam minha identidade, são roupas clássicas com um toque moderno. Sou assim (Entrevistado n. 11).

Acho que o ideal é misturar um pouco de tudo e usar a marca como componente da sua identidade. Ontem, estava assistindo um programa de moda e achei ótimo ver um especialista em moda usando um relógio CK, óculos Armani e uma sandália Havaiana. Mostra que ele possui um estilo próprio, personalidade. Faz seu estilo a partir de misturas (Entrevistado n. 1). 
4) A afirmação "d" (minha(s) marca(s) preferida(s) de vestuário é (são) parte de quem eu sou), apresentou forte tendência a divergências entre os respondentes: um discordou totalmente, quatro ficaram em posição neutra e quatro concordaram plenamente. Alguns exemplos ilustram essa divergência:

Fiz anos de terapia e hoje não preciso mais de roupas de marcas para mostrar quem eu sou. Acredito que a marca não interfere em quem eu sou... Elas apenas complementam de maneira sutil (Entrevistado n. 1).

Adoro a (marca) Forum, mas se ela acabar fazer o quê? (risos) Simplesmente compro outras marcas. A minha vida é cheia de adaptações... Se me adapto com tanta coisa não vou me adaptar com outra marca? Pode roubar tudo (risos) que não faz a menor diferença. Simplesmente compro outras... (risos) (Entrevistado n. 2).

Eu não perderia minha identidade de maneira nenhuma. Se minhas roupas forem roubadas eu simplesmente compro outras. Não sou fiel nem ao meu marido (referindose ao fato de ele, como homossexual, ver a fidelidade de maneira diferente) vou ser fiel a uma roupa? Pode ir lá e roubar tudo (Entrevistado n. 12).

5) A afirmação "e" (se minha(s) marca(s) preferida(s) de vestuário for(em) roubada(s), me sentirei como se perdesse minha identidade) foi a que apresentou maior número de respostas indicando discordância plena. Nesse quesito, pôde-se observar que os entrevistados não manifestaram grande fidelidade em relação aos itens de vestuário adquiridos, como no seguinte trecho de entrevista:

Quando era mais novo eu até poderia pensar assim, mas hoje não. Hoje sou mais eu e não preciso de marca para me sentir mais confiante e muito menos para afirmar minha identidade. Quando era mais jovem eu tinha essa coisa obsessiva com marca, acho que naquela época se você roubasse minhas roupas preferidas eu ia me sentir até um pouco despersonalizado. Lembro que tinha uma calça da Levis que era quase um amuleto. Hoje não estou nem aí para isso. Tenho mais com o que me preocupar... Acho que quem depende de marcas para construir sua identidade é uma pessoa completamente vazia... Bem diferente de mim (Entrevistado n. 4).

6) A afirmação " $f$ " (parte da minha identidade vem de minha(s) marca(s) preferida(s) de vestuário) recebeu discordâncias mais ou menos fortes da parte de seis respondentes. Igual número de respondentes optou pela concordância, dos quais dois concordaram plenamente. Esta divergência pode ser captada em duas passagens selecionadas:

Acho que essa pergunta deveria ser ao contrário. Seria melhor se fosse: "as roupas que uso são parte da minha identidade". Sei lá ... fiquei meio confuso e prefiro discordar mais que concordar (Entrevistado n. 1).

Amo ( $a$ marca) Hering 5 . Para mim a Hering é um luxo. A Hering não concorre comigo. Deixa eu ser quem eu sou. A marca simplesmente me completa. Várias vezes eu estou usando uma camisa branca da Hering e as pessoas me dizem que a camisa é linda. Não é nada. É só uma camisa branca ... quem ressalta a camisa sou eu. Por isso amo Hering. Se estivesse usando uma marca chamativa feito a (marca) Calvin Klein, que é uma marca tipicamente gay, eles estariam elogiando a camisa e não a mim. Entendeu? (Entrevistado n. 9).

${ }^{5} \mathrm{~A}$ citação à marca Hering como "de luxo" em um primeiro momento surpreendeu, já que, tradicionalmente, essa marca não apresenta "DNA de luxo". Ao contrário, suas características são típicas das marcas populares: baixo valor, produção em massa, de fácil acesso, design sem diferenciações. Entretanto, após questionar alguns dos entrevistados que optaram pela marca Hering, percebeuse que ela apresenta um aspecto muito peculiar para o público homossexual em geral: por ser algo de configuração básica, ela não "concorre" com seu usuário - ou seja, não se destaca à frente deste. E isso, no caso dos gays, é relevante porquanto pode-se supor que eles estariam mais interessados do que os heterossexuais em deixar transparecer seu corpo enquanto sinalizador daquilo que são. É como se a marca Hering transpassasse a conotação purista do luxo conforme definido nessa pesquisa, tornando-se algo que, de tão adequado aos propósitos do usuário, passa a ser-Ihe um objeto indispensável 
O que se vê, portanto, é que a pesquisa identificou que não existe unanimidade, por parte dos homossexuais masculinos entrevistados, sobre até que ponto o vestuário de luxo cumpre uma função no desenvolvimento do seu eu estendido. Isso dependeria da personalidade do indivíduo, do seu momento de vida, de sua idade, de sua situação profissional e, até mesmo, de suas necessidades momentâneas - ou seja, do seu perfil de uma forma geral. Em outras palavras, o vestuário de luxo poderia desempenhar papel tanto central como coadjuvante no desenvolvimento do eu estendido deste público.

\subsection{Quanto ao autoconceito}

Esta análise ocorreu por meio da comparação das médias, consolidadas para todos os respondentes, de cada uma das opções da escala semântica para a mediação do autoconceito e do conceito quanto ao vestuário de luxo (ver Figura 7). Com isso, deu-se visibilidade imediata quanto à (in)congruência entre ambas as percepções, autoconceito e conceito, assim como quanto às intensidades dessas aproximações ou afastamentos.

\section{Figura 7 - Médias da escala semântica para o autoconceito e para o conceito de vestuário de luxo}

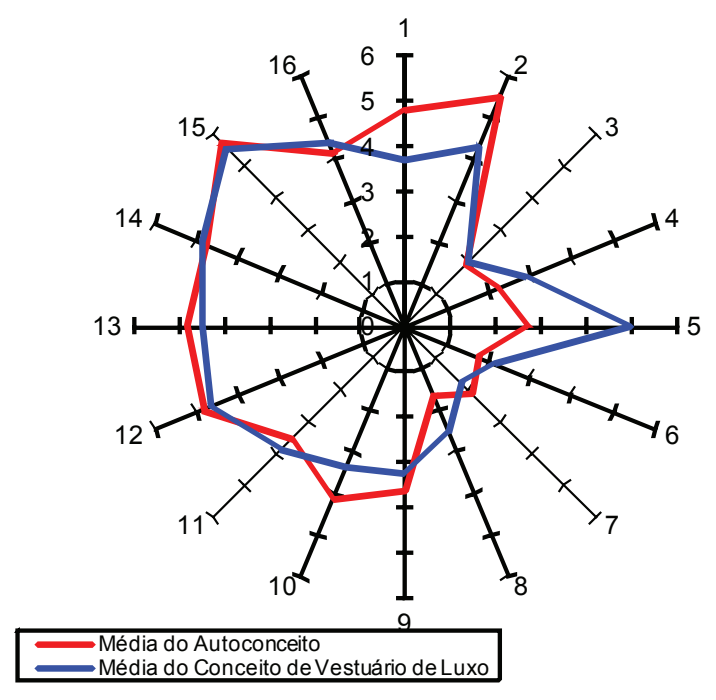

Fonte: Pesquisa

Observou-se que as médias do autoconceito e do conceito quanto ao vestuário de luxo situaram-se muito próximas uma da outra no caso dos pares de adjetivos bipolares de números 3 (informado/desinformado), 14 (sem cores/ colorido), 15 (fraco/ forte) e 12 (conservador/ liberal). Dentre esses pares, o de número 3 (informado/desinformado) foi o que teve maior grau de proximidade, o que se justifica pelo discurso da maior parte dos entrevistados, ressaltando que são muito preocupados com a informação e que a forma de se vestir está diretamente relacionada a ela: 
Meu trabalho me exige ser uma pessoa antenada (Entrevistado n. 6).

Se eu sou ou pelo menos quero ser (risos) uma pessoa informada, é claro que minha marca preferida também vai ser. Afinal, se uso uma determinada marca retrógrada, a tendência é que eu pareça retrógrado. Hoje, como lhe falei, minha marca preferida é a Forum (neste momento o entrevistado fez questão de mostrar a marca impressa na calça que estava usando). Não uso essa marca apenas porque tem um corte legal ou veste bem. Uso Forum porque passa um conceito. É uma marca que está sempre se inovando. Tudo a ver comigo (Entrevistado n. 3).

O segundo item com maior proximidade foi o de número 14 (sem cores/colorido). A maior parte dos entrevistados ressaltou que gostam de ser "coloridos", pois associam cor à alegria ou à brilho, utilizando o vestuário de determinada marca como forma de obter estas características:

Parece que quando uso (a marca) Calvin Klein fico mais sexy, mais atraente (Entrevistado n. 6). Entendo o adjetivo colorido como uma pessoa que se destaca, chama atenção, tem brilho próprio. Estou certo? (o pesquisador respondeu que sim). Então eu me considero um cara super colorido e acredito que as minhas marcas reforçam isso. A (marca) AussieBum (referindo-se a uma de suas marcas preferidas) me ajuda a reforçar ainda mais essa minha cor (risos) (Entrevistado n. 8).

O terceiro item com maior proximidade foi o item 15 (fraco/forte). Aqui pôde-se verificar que muitos dos entrevistados interpretam marcas consideradas por eles como "bem masculinas" para a obtenção de força:

Eu adoro a (marca) Levis porque deixa o corpo bem masculino (Entrevistado n. 7). Não gosto de marca de gay tipo Calvin Klein. Sou homossexual e gosto de homem. Quem gosta de mulherzinha (referindo-se aos que preferem relacionar-se com "bichinhas"') detestaria sair com um cara que se vestisse de Calvin Klein. Para mim, esse cara não tem personalidade, segue um modelo (Entrevistado n. 10).

Já o último par de adjetivos com maior proximidade é a de número 12 (conservador/liberal). Nesse item, a maior parte dos entrevistados mostrou-se liberal em relação à forma de se vestir:

Antigamente (o entrevistado) era super consumista e gostava de comprar o que estava na moda. Hoje não. Acho que, com meus 44 anos muito bem vividos (risos), não preciso mais disso. Me visto da maneira que quero, não sou preso a nada. Antes precisava mostrar - ou melhor, enganar - o que era, com uma camisa de marca tal, mas hoje me libertei disso. Sou uma pessoa liberal, uso o que me der vontade (Entrevistado n. 5).

Como trabalho para mim mesmo (referindo-se ao fato de ser um profissional liberal) posso me vestir conforme meu estilo, minha forma de pensar e agir. E, como sou uma pessoa extremamente liberal, me visto assim. Por exemplo, tem dia que quero usar uma roupa antenada como uma calça bem larga, um relógio grande e uma camisa mais justa; eu ponho e pronto. Sabe, eu me garanto e se tenho a personalidade liberal, eu pago o preço por isso. Não vou ficar me escondendo por detrás de um terno ou de um visual quadradinho (Entrevistado n. 1).

Já em relação aos pares de adjetivos com menores congruências entre o autoconceito e o conceito de vestuário, destacou-se o item 5 (econômico/perdulário). A esse respeito, a marcação na escala semântica para o autoconceito ficou em 2,75 na média de todos os respondentes - ou seja, ficou mais próxima do adjetivo econômico. Contudo, a análise dos discursos mostrou que a maior parte dos entrevistados, na verdade, sente-se perdulária e gostaria de ser mais econômica, ao mesmo tempo em que, usualmente, referiam-se às suas marcas preferidas como

\footnotetext{
${ }^{6}$ Termo usado pelos gays como sinônimo de afeminado e com trejeitos extremamente femininos.
} 
pouco acessíveis. Esse paradoxo nota-se claramente quando eles destacam adorar exclusividade, característica que normalmente encarece o preço da peça:

Sou completamente fissurado por marcas. Já fiz loucuras, tipo estourar cartão de crédito e dever muito... Hoje estou um pouquinho melhor (risos) (Entrevistado n. 8).

Quando quero me presentear compro uma marca bacana, mesmo que o momento não seja propício. Não economizo comigo e pago um preço alto. Meu marido (em tom de confidencialidade) não pode nem imaginar que ando gastando tanto porque estamos construindo (um imóvel), mas infelizmente gosto de coisa boa e isso tem um preço - que, no meu caso, é bem alto (Entrevistado n. 12).

Adoro tudo que é exclusivo. Uma coisa que não citei é que adoro camisas customizadas. Feitas para mim. Muitas vezes elas podem até não ser nada baratas, mas são únicas. Quando uso uma camisa customizada me sinto divino. Penso: ninguém é igual a mim. Sou um luxo (Entrevistado n. 11).

O par de adjetivos do item 2 (agitado/calmo) também apresentou reduzida congruência entre $o$ autoconceito e o conceito de vestuário. Nesse item, a grande divergência entre o autoconceito e o conceito de vestuário possivelmente remeteu aos entrevistados terem demonstrado dificuldade em associar suas roupas especificamente a esse tipo de comportamento. Exemplos são as dúvidas de dois dos entrevistados durante a conversa:

Eu realmente não entendo como vou classificar a marca Forum como calma ou agitada. Esta pergunta tá meio estranha. Você classificaria como? (Entrevistado n. 3).

Acho que para conseguir fazer essa associação vou ter que pensar em um homossexual que use a Diesel, pode ser? Pensando assim fica mais fácil... Por exemplo, meu namorado tem momentos que é bem calmo e em outros está mais para agitado. Então, no caso da Diesel, que ele também adora, vou tentar justificar que depende da coleção ou do estilo daquela roupa. A Diesel tem roupa para a balada, que no caso eu consideraria agitada, mas tem umas camisas mais tranquilas para o dia a dia que poderiam ser consideradas mais tranquilas. Conseguiu entender minha associação? (Entrevistado n. 8).

Outro par de adjetivos que apresentou uma visão paradoxal foi a do item 1 (bruto/ delicado), pois a maior parte dos entrevistados revelou que gostaria de ser vista como delicado embora prefira marcas consideradas por eles como mais brutas:

Não gosto de marcas gays tipo Calvin Klein porque marca muito o corpo. Para mim, homem tem que se vestir como homem. Meu marido adora a CK, mas hoje eu não deixo usar não (risos), acho simplesmente ridículo. Quando ele insiste até usa, mas eu mesmo não gosto. A única coisa de que eu realmente gosto e que é bem gay são os óculos. Óculos de hétero é o fim. Meu rosto é grande, eu ia ficar muito esquisito com óculos de hétero. Nessas horas eu concordo que "oclão" é bem mais charmoso. Mas de fresquinho só... (Entrevistado n. 7).

Dentre os entrevistados pôde-se perceber - e demonstrar através de trechos das entrevistas - que a maior parte dos homossexuais masculinos consome produtos que estão diretamente relacionados com seu autoconceito:

Ainda não consegui o status que desejo. Estou no início de uma longa jornada. Tenho muita vontade de ser um grande advogado. Quero ser respeitado pela minha profissão a tal ponto que a minha opção sexual não interfira mais. Infelizmente, hoje, com 29 anos, estou bem distante disso... (neste momento o entrevistado comentou algumas das dificuldades que passa como advogado no Rio de Janeiro). Acredito que uma das melhores formas para minimizar esse abismo entre o meu autoconceito (como advogado) e o que 
eu quero ser é utilizando roupas que se aproximem dele. Um exemplo é o fato de eu usar apenas terno (da marca) Hugo Boss, que é uma marca que representa exatamente quem eu desejo ser (Entrevistado n.11).

Concordo totalmente que parte da minha identidade vem de minhas marcas. Afinal, marca para mim não é só design, beleza... Marca para mim é atitude, e, na medida em que me proponho a usar determinadas marcas, é sinal que faço parte daquele grupo. Em minha opinião, quando fazemos parte de um grupo, trocamos referências, e essas referências vão fazer parte de nossa identidade (Entrevistado n. 6).

Além disso, percebeu-se que o uso de produtos diferenciados e com alto valor agregado é, em diversas ocasiões, utilizado por estes sujeitos como um instrumento possibilitador para a participação em determinados grupos:

Uma das minhas marca preferidas é a AussieBum. Essa marca é um estouro. Malho muito, me cuido... Acho que tenho tudo a ver com a Aussie (risos): bonito, forte, malhado (risos)... brincadeirinha. A Aussie tem até uma comunidade que faço parte claro. Não é qualquer um que pode fazer parte desse grupo seleto... Para isso, além de usar a marca tem que agir de maneira coerente (Entrevistado n.8).

Quando estou trabalhando procuro usar roupas que passam a ideia de uma pessoa bem sucedida. Por exemplo, adoro os ternos da (marca) Hugo Boss. Penso que quem usa essa marca é bem sucedido, e como esse é meu maior desejo profissional, procuro sempre usar essa marca. Acho que, na minha profissão (advogado), a imagem é bem importante e me ajuda a fazer parte de um seleto grupo (Entrevistado n.11).

Nesta pesquisa, pôde-se até mesmo identificar marcas de vestuário que funcionam como sinalizador da opção sexual do entrevistado, além de diferenciá-lo dentre os demais homossexuais. Isto confirma a posição de Allérès (2000), de Amui (2006) e de Vigneron e Johnson (2004) de que os produtos de luxo, além das qualidades objetiva e subjetiva, funcionalidade e estética, respectivamente, apresentam uma dimensão simbólica que precisa ser considerada:

A (marca) Calvin Klein para mim é sinônimo de poder, status, sucesso. Pensa comigo: quem usa essa marca tem que ter corpão (o entrevistado mostrou o bíceps malhado), tem que ocupar um lugar privilegiado, ou seja, se destacar em um grupo e principalmente ter sucesso pessoal e profissional, porque não é uma marca barata. Eu uso porque tenho 25 anos, me sinto bem e meu corpo está no melhor momento, mas Calvin Klein não é para qualquer um (risos) (Entrevistado n. 8).

Outro ponto determinante extraído da análise do discurso desses entrevistados é o fato de, em diversas ocasiões, eles consumirem produtos de luxo que não "concorram" diretamente com o seu eu e preferirem marcas neutras quando se referem a vestuário:

Gosto de malhar, cuidar de mim, sou super vaidoso. Tem até uns amigos meus que me chamam de Barbie ${ }^{7}$ (risos), mas não sou não... Tenho um corpo legal e, para que possa ressaltar isso, eu prefiro marcas mais discretas que chamem mais atenção para mim do que para a roupa em si. A (marca) Hering me proporciona isso. Uso muito as camisas de malha, as cuecas, bermudas... gosto de quase tudo. Acho que, se você tem uma estética legal, muito enfeite até atrapalha. É engraçado porque sei que posso encontrar 200 pessoas com uma camisa Hering, mas eu de Hering sou diferente (neste momento, o entrevistado bateu no peito, sinalizando orgulho) dos outros 200 afinal, eu sou mais eu (risos) (Entrevistado n. 7).

Ressalta-se, ainda, que a autoimagem do homossexual masculino é parcialmente cons-

${ }^{7}$ Termo usado pelos gays para definir um homossexual do sexo masculino que pratica halterofilismo ou que possui o corpo muito musculoso. 
truída por meio do consumo de produtos do mercado de luxo, especificamente por meio do consumo de marcas específicas de vestuário de luxo que simbolizem sua opção sexual. Assim, podese afirmar que tanto o conceito de autoimagem que o homossexual faz de si mesmo influencia no consumo quanto o tipo de consumo influencia na composição dessa autoimagem. Aqui, mais uma vez a teoria concordou com os resultados da pesquisa; afinal, Belk (1988) defende o princípio de que as posses de um indivíduo são parte de sua identidade:

Minhas marcas preferidas fazem com que eu me sinta da maneira como eu gostaria de ser (Entrevistado n.12).

Assim, como os produtos de luxo são, relembrando Amui (2006), mais do que qualquer outro produto, comprados não por aquilo que são, mas pelo que significam, além de possuírem cinco dimensões - conspicuidade, exclusividade, qualidade, hedonismo e a extensão do eu - pode-se concluir que existe influência direta desses na formação do autoconceito dos homossexuais.

\section{CONCLUSÕES, LIMITAÇÕES E RECOMENDAÇÕES}

Os resultados desta pesquisa permitem concluir que não existe consenso entre os entrevistados sobre até que ponto o consumo de vestuário de luxo por parte dos homossexuais masculinos cumpre uma função no desenvolvimento do seu eu estendido: dependendo do perfil do homossexual (idade, situação profissional), este papel pode ser tanto central como coadjuvante. Um extrato de entrevista ilustra este aspecto:

Estou muito bem comigo mesmo. Já atingi quase tudo que planejei para mim. Hoje,
posso dizer que as minhas roupas estão em total sintonia com o que eu sou. Não preciso
mais utilizar determinado estilo de roupa para aparentar o que eu não sou e que eu
talvez quisesse ser. Hoje, uso roupas que realmente são compatíveis com o que eu sou.
Talvez o que possa variar é meu humor no dia. Se estou mais leve (referindo-se a estado
de espírito) vou querer usar uma roupa mais clara, mais leve. Se estiver naqueles dias
(também referindo-se a estado de espírito) vou preferir algo mais discreto. Acredito que
nesse meu momento eu utilizo, sim, as roupas para demonstrar quem eu realmente sou
ou estou. Complexo? Acho que respondi a função do vestuário na minha vida, certo?
(Entrevistado n.1).

Ademais, pode-se perceber que os valores fundamentais que orientam o consumo dos produtos de luxo para este público envolvem status, percepção de exclusividade por meio do uso de produtos diferenciados e com alto valor agregado e possibilidade de participação em determinados grupos através da aquisição de alguns produtos. Isso confirma a posição de Allérès (2000), de Amui (2006) e de Vigneron e Johnson (2004) de que os produtos de luxo, como já afirmado, além das qualidades objetiva e subjetiva possuem uma dimensão simbólica a ser considerada. Conforme Amui (2006), mais do que qualquer outro produto, os itens de luxo são comprados não por aquilo que são, mas pelo que significam, além de possuírem as cinco dimensões já citadas (a conspicuidade, a exclusividade, a qualidade, o hedonismo e a extensão do eu).

Da mesma forma, pode-se identificar que não existe unanimidade na forma como o vestuário de luxo pode contribuir para a construção da autoimagem do consumidor e do seu eu estendido. Isto ocorre porque essa variaria de acordo com a personalidade do indivíduo, com seu momento de vida e, inclusive, com suas necessidades momentâneas. Uma comprovação disso é o discurso apresentado pelo entrevistado n. 11, no qual ele afirma que utiliza o vestuário para construir sua autoimagem de acordo com o ambiente físico em que se encontra, de forma a re- 
presentar diferentes papéis sociais:

Em ambas as ocasiões (quando sai com amigos ou quando vai trabalhar) me preocupo em estar bem vestido, mas tem um estilo para cada ocasião [...] Em relação às marcas, adoro (a marca) Aramis para sair com amigos héteros, visitar minha família (que mora em Brasília) ou ir em festas do escritório. Para trabalhar não existe nada melhor que um terno da Hugo Boss. Deixa qualquer cara lindo, você não acha? Já para me jogar em uma balada, para ir para a pegação, nada mais gay que uma camiseta e um jeans da Calvin Klein. Eu adoro a Calvin Klein, principalmente quando estou em um ambiente muito gay. Parece que quando uso Calvin Klein fico mais sexy, mais atraente (Entrevistado n. 11).

Em relação às limitações desta pesquisa, podem-se apontar três: 1) a possível influência dos pontos de vista do pesquisador na interpretação dos resultados, característica da metodologia qualitativa; 2 ) a eventual incapacidade do pesquisador, durante a coleta de dados com autilização de formulário, de captar aspectos relevantes que, às vezes, não são explicitamente revelados e que devem ser inseridos dos discursos dos entrevistados e 3) a possibilidade de o entrevistado nem sempre oferecer respostas corretas, que reflitam sua opinião real, por razões que variam desde falhas do entrevistador que não passem confiança até questões pessoais conscientes ou inconscientes.

Finalmente, como sugestões para futuros estudos, pode-se sugerir a investigação sobre a existência de influências do grupo homossexual masculino na escolha da marca por parte dos indivíduos isoladamente, assim como a replicação desta averiguação com homossexuais femininas.

\section{REFERÊNCIAS}

AAKER, D. A. Marcas, brand equity: gerenciando o valor da marca. São Paulo: Negócio, 1998

ALLÉRÈS, D. Luxo...estratégias, Marketing. Rio de Janeiro: FGV, 2000.

ALTAF, J. A relação entre o eu estendido do público homossexual masculino e seu consumo de vestuário de luxo. Dissertação (Mestrado). Universidade Estácio de Sá, Mestrado em Administração de Empresas, 2009, $161 \mathrm{p}$.

AMUI, I. C. Comportamento do consumidor de cosméticos de luxo: um estudo exploratório. 2006. 112 f. Dissertação (Mestrado em Administração) - Universidade Federal do Rio de Janeiro, Rio de Janeiro, 2006.

AZEVEDO, M.; MARTINS, C.; PIZZINATTO, N.; FARAH, O. Segmentação no Setor Turístico: O Turista LGBT de São Paulo. Rev. Adm. UFSM, Santa Maria, v. 5, n. 3, p. 493-506, set/dez,
2012

BALDISSERA, R. Comunicação organizacional. In: Comunicação organizacional. 0 treinamento de recursos humanos como rito de passagem. São Leopoldo: UNISINOS, p. 1339,2000

BAUDRILLARD, J. O sistema dos objetos. São Paulo: Perspectiva, 1973.

BAUDRILLARD, J. A sociedade de consumo. Lisboa: Edições 70, 1981.

BELK, R. Possessions and the extended self, Journal of Consumer Research, v. 15, p.139168, 1988.

BIEL, A. How brand image drives brand equity. Journal of Advertising Research, November, Vol. 32 No.6, pp.RC6-RC12, 1992

BOWES, J. E. Out of the closet and into the marketplace: meeting basic needs in the gay community. In: WARDLOW, D. L. (ed.) Gays, lesbians, and consumer behavior: theory, practice, and research issues in Marketing. New York: Harrington Park, p. 219-244, 1996. 
CAMPOS, R.; SUAREZ, M.; CASOTTI, L. Possibilidades de contribuição da sociologia ao Marketing: itinerários de consumo. Anais do II EMA (Encontro de Marketing da ANPAD). Rio de Janeiro, 2005.

CASTARÈDE, J. O luxo - os segredos dos produtos mais desejados do mundo. São Paulo: Barcarolla, 2005.

CAVALLET-MENGARELLI; A. P. R. Interações entre autoconceito e personalidade da marca nas representações de consumo de adolescentes. 2008. 187f. Dissertação (Mestrado em Administração) - Universidade Federal do Paraná. Curitiba, 2008.

CHURCHILL JR., G. ; PETER, J. P. Marketing: criando valor para os clientes. São Paulo: Saraiva, 2000

CONSTÂNCIO, J. R. Branding e mercado GLS: um encontro de valor. Encontro do SINAP Simpósio Brasileiro de Gestão de Negócios Portuários. Universidade Católica de Santos (Unisantos). Santos: 2007.

D'ANGELO, A. C. Valores e significados do consumo de produtos de luxo. $209 \mathrm{f}$. Dissertação (Mestrado em Administração) Universidade Federal do Rio Grande do Sul. Porto Alegre, 2004.

DELOIZER, M. W.; RODRIGUES, J. Marketing to the homossexual (gay) market: a profile and strategy implications. In: WARDLOW, D. L. (ed.) Gays, lesbians, and consumer behavior: theory, practice, and research issues in Marketing. New York: Harrington Park, 1996, p. 203-212.

DORON, R; PAROT, F. Dicionário de psicologia. São Paulo: Ática, 1998.

EISENHARDT, K. M. Building theories from case study research. Academy of Management Review, v. 14 , n. 4, p. 532-550, 1989.

GARDNER, B. B. E. ; LEVY, S. J. The product and the brand. Havard Business Review. 33:33-9, mar-apr., 1995

GASKELL, G. Entrevistas individuais e grupais. In: Pesquisa qualitativa com texto, imagem e som- um manual prático. 3. ed. Petrópolis: Vozes, 2004.

GRANATO, L.; PEREIRA, P. Ainda existem consumidores fiéis? Rev. Adm. UFSM, Santa Maria, v. 4, n.1, p. 09-18, jan./abr, 2011

GRUBB, E. L.; GRATHWHOHL, H. L. Consumer self-concept, symbolism and market behavior: theoretical approach, Journal of Marketing, 31 (3nd ed.), 256- 275, 1967.

HAIE, V. Donnez-nous notre luxe quotidien. Paris: Gualino. , 2002

HAWKINS, D. L.; MOTHERSBAUGH, D. L.; BEST, R. J. Comportamento do consumidor: construindo a estratégia de Marketing. Rio de Janeiro: Elsevier / Campus, 2007.

HIRSCHMAN, E.; HOLBROOK, M. Hedonic consumption: emerging concepts, methods and propositions. Journal of Marketing, vol. 46, summer, 1982.

HOLBROOK, M.; BLOCK, L.; FITZSIMONS, G. Personal Appearance and Consumption: a framework for descriptive and prescriptive analysis. Consumption, Markets and Culture, vol. 2, n. 1, p.1-55. 1996.

KELLER, K. L. Conceptualizing, measuring and managing customer-based brand equity. Journal of Marketing. V. 1, n.57, 1993

LIPOVETSKY, G.; ROUX, E. O luxo eterno: da idade do sagrado ao tempo das marcas. São Paulo: Cia das Letras, 2005.

LUKENBILL, G. Untold Millions: secret truths about Marketing to gay and lesbian consumers. New York: Harrington Park Press, 1999.

MALHOTRA, N. K. A scale to measure selfconcepts, person concepts, and product concepts. Journal of Marketing Research, 
publicado pela American Marketing Association; reimpresso com permissão, nov. 1981, p.462.

MARIANO, F.; LIMA, E. O Consumidor Saindo do Armário: o público homossexual e a mídia. São Paulo: L2 Pesquisas e Comunicação, 1999. Disponível em < http://www.estadao.com. $\mathrm{br} /$ premiodemidia/2/trabalhos/consumidor_ saindo_do_armario.pdf> Acesso em 19 out 2010.

MCCRACKEN, G. Culture and consumption: a theoretical account of the structure and movement of the cultural meaning of consumer goods. Journal of Consumer Research, v. 13,1986 .

MINISTÉRIO DA SAÚDE/IBOPE. Pesquisa IBOPE 2002 - HSH. Disponível em <http://www.aids. gov.br/final/novidades/opp\%20129\%20-\%20 Homens.ppt>. 2002. Acesso em 26 ago 2010

NUNAN, A. Homossexualidade: do preconceito aos padrões de consumo. Rio de Janeiro: Caravansarai, 2003.

PINTO, M.; LARA, J. O que se publica sobre comportamento do consumidor no Brasil, afinal? Rev. Adm. UFSM, Santa Maria, v. 1, n. 1, p. 85-100, jan./abr., 2008

ROCHA, E. Sociedade do sonho: comunicação, cultura e consumo. Rio de Janeiro: Mauad, 1995.

REED II, A. Social Identity as a useful perspective for self-concept-based consumer research. Psychology \& Marketing, v. 19, n. 3, p. 551564, 2002.

RICHINS, M. L. Social comparison and the idealized images of advertising. Journal of Consumer Research, v. 18, 1991.

ROSEMBERG, M. Conceiving the Self. New York: Basic Books, 1979.

ROSS, I. Self-concept and brand preference. Journal of Business of the University of
Chicago, v. 44, n. 1, 1971.

SCHENK. C. T. ; HOLMAN R. H. A Sociological Approach to Brand Choice: The Concept of Situational Self-Image. Advances in Consumer Research. 7 (2nd ed.), 610-614, 1980.

SIRGY, M. J. Self-concept in consumer behavior: a critical review. Journal of Consumer Research, v. 9, n.3, 1982.

SIVADAS, E.; MACHLEIT, K.A. A scale to determine the extent to object incorporation in the extended self. In: PARK, C. W.; SMITH, D. C. (ed.).Marketing theory and applications, v. 5, Chicago: American Marketing Association, 1994.

SOARES, J. C. O Dinheiro Que Ousa Dizer o se Nome: o Mercado GLS e suas repercussões. 2000. 96 f. Monografia de Conclusão de Curso. UFF, Departamento de Comunicação Social, Rio de Janeiro, 2000.

SOLOMON, M. The role of products as social stimuli: a symbolic interactionism perspective. Journal of Consumer Research, v. 10, n.3, 1983.

SOLOMON, M. O comportamento do consumidor: comprando, possuindo, sendo. 5.ed. Porto Alegre: Bookman, 2002.

TAVARES, M. C. A força da marca. São Paulo: Harbra, 1998

TIAN, K.; BELK, R. Extended Self and Possessions in the Workplace. Journal of Consumer Research, v. 32, n. 2, p. 297-310, December, 2005

VIGNERON, F.; JOHNSON, L. Measuring perceptions of brand luxury. Jounal of Brand Management, v. 11, n. 6, p. 484-506, 2004. 